engineers are sometimes complicit with this process. Sudan's Merowe dam on the Nile could be set to repeat the mistakes that have characterized previous large-scale hydropower projects in poor countries. Studies of how to resettle 50,000 people whose land will be flooded, and assessments of the project's environmental impact, were finished late in the day, and undertaken with insufficient rigour. They would have stopped the project going ahead if the World Bank, for example, was funding it.

Lahmeyer International, the German company that is coordinating the project, is disarmingly open about why this is so. It says that funders such as the World Bank make things too complicated. Thorough environmental and social impact assessments take years; Sudan wants power now. China is willing to invest, in part to cement closer ties with an important oil producer. And the Sudanese government lacks the political infrastructure - and probably the political will - to enforce proper safeguards. So, once again, thousands of poor people look set to suffer so that a big dam project can go ahead.

The project's backers have sought to portray Merowe as a necessary trade-off between the competing needs of development and the rights oflocal people. But there is no reason why both needs can't be met. Hydropower certainly has a role to play in Africa's development. Most of the continent's available hydropower resources are untapped and could, if properly harnessed, provide a valuable and renewable source of energy. But that doesn't mean that large dams need to be built. Successful projects in Asia and South America have shown that small hydropower projects can supply a few thousand local people without the need for big resettlement projects. Smaller projects can be run with more input from local people and are easier to combine with other renewable sources, such as solar power.

Unless the lessons of the past are thoroughly learned, large dam projects will sink over time in a morass of corruption, haphazard displacement of local people, lack of political accountability, and failure to plan properly for maintenance.

South Africa has, to its credit, tried to incorporate some of these lessons into a hydropower and water-supply project in Lesotho. The project is imperfect, but at least its administrators have sought to consult with local people and to run independent assessments of its environmental impact. But South Africa, with its wealth "People's rights and needs are once again being sidelined in the stampede for wealth." and its relatively sophisticated political system, is an exception.

In many other African nations, there is little chance of proper safeguards being implemented. Chinese firms and government agencies will operate with few checks or balances. The same goes for the European companies involved in Merowe and elsewhere. They know that rigorous political consultation and environmental assessment are needed if big dam projects are to succeed. Yet they have been happy to engage in such projects in the absence of any such safeguards. The staff and shareholders of these firms are part of another scramble for Africa, in which local peoples' rights and needs are once again being sidelined in the stampede for wealth.

\section{A colourful past}

\section{The production of dyes in the nineteenth century marked a turning point in the appliance of science.}

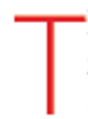
he 150th anniversary of William Perkin's synthesis of aniline mauve dye (see page 429) is more than just an excuse to retell a favourite story from chemistry's past. To be sure, the tale contains much to delight in: Perkin's extraordinary youth and good fortune, the audacity of his gamble in setting up a business to massproduce the dye, and the chromatic riches that so quickly flowed from an unpromising black residue of coal-gas production. But perhaps the most important aspect of the story is the relationship that it engendered between pure and applied science.

The demand for new, brighter and more colourfast synthetic dyes, along with new means of setting them on to fabrics ('mordanting'), stimulated manufacturing companies to set up their own research divisions, and thus cemented interactions between industry and academia that were just developing at the time.

Traditionally, dye-making was a craft, a combination of trial-anderror experimentation and the rote repetition of time-honoured recipes. The idea that chemical production required real scientific expertise did not arise until the eighteenth century, when the complexities of mordanting and multicolour fabric printing moved beyond the expertise of mere recipe-followers.

That was when the Scottish chemist William Cullen announced that if the mason wanted cement, the dyer a dye and the bleacher a bleach, "it is the chemical philosopher who must supply these". Making inorganic pigments preoccupied some of the greatest chemists of the early nineteenth century, notably Nicolas-Louis Vauquelin, Louis-Jacques Thénard and Humphry Davy. Perkin's mauve, however, was an organic compound and so, in the mid-nineteenth century, was rather more mysterious than metal salts. The drive to understand the molecular structure of carbon compounds during this period is often presented today as 'pure' chemistry, but in reality it owed much at the time to the profits that might ensue if the molecular secrets of organic colour could be unlocked.

Both the need to understand molecular structure and the demand for synthetic methods were sharpened by chemists' attempts to synthesize indigo
"Dye companies, including Bayer, Ciba and Geigy, had seen the value of havinghighly skilled chemists on their payroll." and alizarin (the natural colour obtained from the madder plant). When Carl Graebe and Carl Liebermann found a route to making alizarin in 1868, the Badische dye company, soon to become BASF, quickly acquired the rights. One of those who found a better route in 1869 was Ferdinand Riese, who was already working for Hoechst. Another was Perkin.

These and other dye companies, including Bayer, Ciba and Geigy, had seen the value of having highly skilled chemists on their payroll - something that was even more evident when they branched into pharmaceuticals early in the twentieth century. Thus, today's integration of scientific research into industry first began to take shape, as companies realized that good business needs good scientists. 